\title{
Religie, Bijbel en geweld
}

\author{
J W van Henten ${ }^{1}$ \\ Universiteit van Amsterdam \\ Nederland
}

\author{
Abstract \\ Religion, Bible and violence
}

This contribution is the slightly adapted introductory lecture given at the conference on the New Testament and Violence held in Stellenbosch from 21-23 January 2008. The lecture offers a personal survey of some of the recent contributions with regard to the nexus of religion and violence and their relevance for New Testament studies. The work of René Girard, Regina Schwartz, Mark Juergensmeyer and $\mathrm{J}$ Howard Ellens is discussed in particular.

\section{INLEIDING}

In 2000-2001 schreef ik een monografie over martelaarschap van Joden en christenen in Jeruzalem. 's Middags werkte ik meestal in de Nationale Bibliotheek, die onderdeel is van de Givat Ram campus van de Hebreeuwse Universiteit. Elke dag zag ik bij binnenkomst en vertrek uit de leeszaal voor Joodse studies een schitterend glas-in-lood-raam van Marc Chagall oplichten, dat het visioen van de Profeet Jesaja "Van zwaarden tot ploegscharen ..." (Jes 2) verbeeldt. Maar op weg naar huis, via de route naar Ramallah, zag ik leuzen op Palestijnse busjes als "liever dood dan onvrij". Meer dan eens las ik in de krant over een interview met de moeder van een Palestijn die zijn leven opgeofferd had voor de Palestijnse zaak, en moest daarbij aan de Moeder van de Makkabese martelaren denken (2 Mak 7). Het was het jaar waarin de Tweede Palestijnse Intifada begon. De contrastrijke, gewelddadige, maar ook inspirerende context in Israël gaf een nieuwe dimensie aan de klassieke martelaarsteksten die ik aan het bestuderen was. Ik was niet alleen gefrappeerd door de actualiteit die deze teksten nog steeds hebben, maar

\footnotetext{
${ }^{1}$ Deze bijdrage is een licht bewerkte inleiding voor de conferentie "Die Nuwe Testament en geweld" in Stellenbosch, 21-23 januari 2008. Prof dr Jan Willem van Henten (Directeur: Graduate School, Universiteit van Amsterdam) is als gastonderzoeker (in samenwerking van prof dr Pieter $\mathrm{G}$ de Villiers van de Universiteit van die Vrystaat) betrokken by het hermeneutiek-project van prof dr Andries $\mathrm{G}$ van Aarde in de Afdeling Nieuw Testamentische Wetenschap van de Faculteit Theologie, Universiteit van Pretoria.
} 


\section{Religie, Bijbel en geweld}

werd me door mijn nieuwe context ook meer bewust van de complexe en ambigue relatie tussen martelaarschap en geweld.

De brute aanval op de Twin Towers in 2001 heeft de westerse wereld geschokt en tot nog meer geweld geleid met de War on terror. Juist door 9/11 wordt martelaarschap tegenwoordig in één adem met geweld genoemd. Ook in Afrika worden velen helaas dagelijks met geweld geconfronteerd, direct of indirect door de complexe erfenis van het kolonialisme en de apartheid in Zuid-Afrika. De genocide in Ruanda heeft diepe nieuwe trauma's veroorzaakt. Terwijl ik dit schrijf (juni 2008) heeft de oppositionele partij van Morgan Tsvangirai in Zimbabwe onder de druk van het grove geweld van de regering van Robert Mugabe besloten niet aan de tweede ronde van de nationale verkiezingen deel te nemen, maar de verkiezingen gaan gewoon door. Het is niet moeilijk meer voorbeelden te vinden. Belangrijk voor deze bijdrage echter is dat uitbarstingen van geweld - met name uitingen van extreem geweld vaak aan religie toegeschreven worden. Zo lijkt in Nederland de populistische politicus Geert Wilders een kruistocht te voeren tegen de Islam omdat deze religie tot geweld zou oproepen en worden conflicten in Noordelijk en Centraal Afrika vaak beschreven aan de hand van de scheidslijn tussen Islam enerzijds en andere godsdiensten anderzijds.

Mijn bijdrage over de verbanden die tussen religie, Bijbel en geweld bestaan heeft een vertrekpunt in twee tegenstrijdige observaties die aan recente discussies over religie en geweld ontleend worden:

- In het wetenschappelijke debat over geweld en radicalisme wordt regelmatig betoogd dat religie geweld legitimeert of zelfs een belangrijke rol speelt als inspiratiebron van geweld.

- $\quad$ Tegelijkertijd is het duidelijk dat religie, zowel binnen het christendom als daarbuiten, als een belangrijke bemiddelende en helende factor functioneert, die mensen helpt met ervaringen van geweld om te gaan.

Wat de Bijbel aangaat is er voor deze punten duidelijk een verschuiving waar te nemen. Terwijl voorheen de boodschap van de Bijbel vaak eenduidig als een oproep tot vredestichting en verzoening opgevat werd (Yoder 1972), hebben recente publicaties tot het inzicht geleid dat er zowel in het Oude als in het Nieuwe Testament conflicterende gezichtspunten over geweld gepresenteerd worden (Schwartz 1997; Assmann 1997; Desjardins 1997; Matthews \& Gibson 2005). Naast het visioen van Jesaja 2 of de zaligspreking van Jezus in Matteüs 5:9 "Gelukkig de vredestichters, want zij zullen kinderen van God genoemd worden", vinden we niet alleen gewelddadige woorden en metaforen in de Bijbel, maar ook negatieve stereotyperingen van mensen, en soms zelfs oproepen tot geweld. 
Mijn bijdrage zal geen uitputtende behandeling van de Bijbelse passages zijn die op enige wijze met geweld in verband gebracht kunnen worden; het zal evenmin een omvattende bespreking van theorieën over het verband tussen religie en geweld zijn. Ter inleiding van onze conferentie over Geweld en het Nieuwe Testament wil ik hier een beknopte en persoonlijke impressie geven van enkele theorieën over religie en geweld die naar mijn mening relevant zijn voor de bestudering van het thema Geweld in het Nieuwe Testament. Ik zal eerst een korte inleiding geven over de desbetreffende theorie en vervolgens enkele opmerkingen maken over de relevantie ervan voor het thema. Achtereenvolgens komen studies van René Girard, Regina Schwartz, Mark Juergensmeyer en J Howard Ellens aan de orde. Ik begin met enkele definities van geweld en eindig met een conclusie.

\title{
2. DEFINITIES VAN GEWELD
}

Voordat de relevante theorieën aan bod komen, moet eerst het begrip geweld omschreven worden. Visies op geweld in het Nieuwe Testament zijn afhankelijk van de gevolgde definitie. De klassieke visie is dat geweld zich toespitst op de fysieke consequenties ervan. Het gezaghebbende Nederlandse woordenboek van Van Dale (1976:808) relateert geweld aan de begrippen "macht" en "kracht" en omschrijft geweld als: "Misbruik van macht, toepassing van het recht van de sterkste, gewelddadigheid".2

In mijn studententijd, kort na de studentenopstanden in West-Europa in 1968, was de instrumentele benadering van geweld van Hannah Arendt (1970) populair. Arendt maakt een onderscheid tussen macht en geweld. Macht is een positief begrip voor haar: macht is het menselijk vermogen om in eensgezindheid en overeenstemming met elkaar te handelen (Arendt 1970:54). Geweld heeft een negatieve lading en is een middel dat zich bedient van werktuigen. Geweld treedt op waar macht in gevaar is, maar geweld kan niet voorkomen zonder dat er een machtsbasis is, al was het maar de geheime politie:

\begin{abstract}
Geweld ... onderscheidt zich als gezegd door zijn instrumentaal karakter. Fenomenologisch staat het het dichtst bij sterkte, daar de instrumenten van geweld, zoals alle andere gereedschappen, ontworpen en gebruikt worden met het doel natuurlijke sterkte te vermenigvuldigen tot $z e$, in het laatste stadium van hun ontwikkeling, ervoor in de plaats kunnen treden.
\end{abstract}

(Arendt 1970: 56; zie ook 61, 96, 106)

\footnotetext{
2 Die daarnaast "macht", "uiting van macht, kracht," "kracht die met hevigheid wordt uitgeoefend" en "zeer sterk gedruis" als betekenissen geeft.
} 


\section{Religie, Bijbel en geweld}

In deze definitie van Arendt valt op dat er geen tegenstelling fysiek - nietfysiek gemaakt wordt, want de "middelen" waarvan geweldplegers zich bedienen kunnen ook niet-fysiek zijn.

Het voorbeeld van Arendt laat ook zien dat definities van geweld samenhangen met ontwikkelingen in de samenleving. Sinds de tachtiger jaren van de vorige eeuw is de visie op geweld in de samenleving - in elk geval in het westen - sterk veranderd. Sindsdien is er veel meer aandacht voor huiselijk geweld, geweld op school en seksueel geweld. In Nederland heeft deze tendens bijvoorbeeld geleid tot het besluit dat de zogenaamde "pedagogische tik" van een ouder die zijn kind wil straffen of corrigeren strafbaar is. Daarnaast is het besef opgekomen dat de rollen van dader en slachtoffer veel minder eenduidig zijn dan vroeger gedacht werd. Deze rollen kunnen gedeeltelijk samenvallen, zodat een geweldspleger ook slachtoffer kan zijn en omgekeerd. ${ }^{3}$ Dergelijke ontwikkelingen hebben volgens de Amerikaanse godsdienstwetenschapper Robert McAfee-Brown geleid tot een verschuiving van de benadering van geweld: velen erkennen nu dat geweld niet alleen fysiek van aard kan zijn, maar ook een niet-fysiek, bijvoorbeeld verbaal, karakter kan hebben (McAfee-Brown 1987:1-14). In een recente studie over geweld in het Nieuwe Testament sluit Michel Desjardins dan ook expliciet aan bij McAfee Brown in zijn eigen definitie van geweld:

First, violence is an overt physical destructive act carried out by individuals or countenanced by institutions ... Second, violence is also a personal and institutional act which ... violates the personhood of another in ways that are psychologically destructive rather than physically harmful.

(Desjardins 1997:12; McAfee Brown 1987:8)

Sommige wetenschappers staan een nog ruimere definitie van geweld voor. Zo omschrijft de godsdienstwijsgeer Hent de Vries (2002:1) geweld als het effect dat uitgeoefend wordt door de ander of door iets anders:

Violence, in both the widest possible and the most elementary senses of the word, entails any cause, any justified or illegitimate force, that is exerted - physically or otherwise - by one thing (event or instance, group or person, and, perhaps, word and object) on another. Violence thus defined finds its prime model - its source, force, and counterforce - in key elements of the tradition called the

\footnotetext{
${ }^{3}$ Vergelijk Psalm 137, daarover Brenner (2004). De gedeeltelijke overlap van de rollen van dader en slachtoffer is ook een belangrijk thema in Coetzee (1980).
} 
religious. It can be seen as the very element of religion. No violence without (some) religion; no religion without (some) violence.

Het valt op dat deze definitie niet alleen niet-fysiek erkent, maar ook een onlosmakelijk verband tussen religie en geweld veronderstelt. Sommige lezers zullen deze omschrijving te vaag en algemeen achten om zinvol te kunnen zijn. De implicatie van de definitie van de Vries lijkt immers te zijn dat bijna elke handeling een gewelddadig karakter heeft. Niettemin verdient ook deze definitie het om vermeld te worden, ook omdat één van de monografieën over geweld in de Bijbel een invalshoek op geweld kiest, die sterk overeenkomt met de benadering van de Vries (Regina Schwartz, zie paragraaf 4).

\section{RENÉ GIRARD}

De theoretische verhandelingen van de Frans-Amerikaanse literatuurwetenschapper en cultuurcriticus René Girard over religie en geweld hebben wereldwijde bekendheid gekregen. ${ }^{4}$ Girard zelf behandelt regelmatig Bijbelse passages in zijn betoog over de wisselwerking van religie en geweld, maar leerlingen hebben zijn werk expliciet toegepast op de Bijbel. ${ }^{5}$ Girard biedt een universele theorie, die zowel voor primitieve culturen als voor de hedendaagse samenleving het directe verband verklaart dat er zijns inziens tussen geweld en religie bestaat. Zijn verklaringsmodel baseert zich niet op de schaarste in de samenleving of op de menselijke agressie, maar op de begrippen offer en zondebok. De menselijke cultuur vindt zijn oorsprong in het collectieve geweld dat met offer en zondebok samenhangt. Al naargelang de publicatie van Girard die men leest staat de zogenaamde mimetische rivaliteit (zie onder) of het mechanisme van de zondebok centraal. Ik haak bij de tweede invalshoek aan, die het meest uitgewerkt te vinden is in Girard's boek De Zondebok (Girard 1986).

Het zich steeds herhalende patroon van het offeren van de zondebok en de daaropvolgende vergoddelijking van de zondebok neemt Girard telkens weer waar in de mythische verhalen van de verschillende culturen. Girard (1977; 1986:33-59) betoogt dat mythen de neerslag vormen van een werkelijke crisis in de samenleving en het collectieve geweld om die crisis te bezweren. Mythen gaan dus op een werkelijk offer van een zondebok terug. Psychologische theorieën bevestigen dit patroon (zie met name Freud en diens interpretatie van de Oedipusmythe). Girard geeft in De Zondebok een middeleeuwse tekst over de pest in Frankrijk in de jaren 1349-50 als

\footnotetext{
${ }^{4}$ Zie voor een biografische schets Girard \& Williams (1996:1-6). Zie voor het Nederlandse taalgebied Lascaris (1987). Zie ook Vos (2006:383-401).

${ }^{5}$ Zie bijvoorbeeld Hamerton-Kelly (1992) en vergelijk de kritiek van Gager (2005).
} 


\section{Religie, Bijbel en geweld}

voorbeeld: Guillaume de Machaut's Jugement du Roy de Navarra. Hij noemt dit werk een "vervolgingstekst" (Girard 1986:17). De Joden functioneren hier als zondebok, omdat ze de waterbronnen vergiftigd zouden hebben. Girard is niet geïnteresseerd in de vraag of de gruwelijke details in deze tekst historisch zijn of niet, het gaat hem erom dat deze tekst in combinatie met andere vervolgingsteksten onder het oppervlakte-niveau van de tekst een "netwerk van historische kennis" laten zien dat wijst op een telkens terugkerend patroon, dat uit vier stereotypische fasen van vervolging bestaat:

- $\quad$ Een crisis (natuurramp, droogte, honger; politiek of religieus conflict) verstoort de orde in de samenleving.

- De schuld van deze crisis wordt geprojecteerd op een individu of een groep.

- Individu of groep beantwoordt aan de stereotypen van de zondebok, zoals onder meer uit de beschuldiging blijkt (kannibalisme, kindermoord, vergiftiging van water, incest, hekserij). De zondebok behoort vaak tot een minderheid.

- $\quad$ Het offer: het doden van de zondebok.

De zondebok heeft uiteindelijk een dubbele functie in de samenleving. Het offer van de zondebok zorgt eerst voor de terugkeer van de orde in de samenleving. Vervolgens ontwikkelt de zondebok zich tot het symbool of de personificatie van de orde, waardoor de verhouding tussen vervolgers en zondebok wordt omgekeerd. De vergoddelijking van de zondebok door de vervolgers brengt de sacrale dimensie in de samenleving tot stand en leidt zo tot "cultuur" (Girard 1986 58). Daarmee ligt het proces van het offer en de daaropvolgende verering van de zondebok ten grondslag aan religie en cultuur. Het zal duidelijk zijn dat in dit theoretische model geweld en religie onlosmakelijk aan elkaar gekoppeld zijn, omdat het offer van de zondebok geweld veronderstelt. Dit wordt bevestigd door Girard's andere invalshoek, die van de mimetische rivaliteit, die met andere accenten tot eenzelfde model leidt. In de meest primitieve vorm hebben persoon $A$ en persoon $B$ een mimetisch verlangen naar hetzelfde object, en dit wederkerige verlangen genereert geweld: “... or rather violence is the process itself when one or more partners try to prevent one another from appropriating the object they all desire through physical or other means" (Girard \& Williams 1996:9). 
Deze mimetische rivaliteit vormt het hart van de rituelen in primitieve samenlevingen. Het overwinnen van de chaos waarover de mythen verhalen moeten ook in termen van deze rivaliteit geïnterpreteerd worden. Het springende punt is dat de wanorde wordt weggenomen met het offer van de zondebok (Girard \& Williams 1996:9-19; Girard 1977; Girard, Oughourlian \& Lefort 1987).

Zoals gezegd hangen religie en geweld direct met elkaar samen in de theorie van Rene Girard. Hij zegt dat zelf ook expliciet: geweld vormt voor hem "de aard en de oorsprong van het religieuze" (Girard 1986:115). De koppeling van geweld en religie is volgens Girard ook sterk aanwezig in de Bijbel, maar uit Bijbelse passages licht ook een tegenbeweging op die Girard met een openbaringskracht in verband brengt. Deze tegenbeweging toont de doorbreking van de magische causaliteit van het zondebok mechanisme en de stereotiepe beschuldigingen die daarbij horen. Girard denkt daarbij bijvoorbeeld aan Juda die de plaats van Benjamin wil innemen als gevangene van Jozef (Gen 44), aan Job en aan de kritiek op de offercultus in Jesaja 2 (Girard \& Williams 1996:18). Ook Jezus wordt geofferd als zondebok, maar sommige passages in de lijdensverhalen van het Nieuwe Testament laten de doorbreking van het patroon van de zondebok zien. Girard denkt daarbij aan passages als Johannes 15:25, waar Jezus spreekt over de haat van de wereld jegens hem: "Zo ging in vervulling wat in hun wet geschreven staat: 'Ze hebben mij zonder reden gehaat."' Deze uitspraak verwijst naar Psalm 35:19 en toont dat Jezus geen blaam treft voor de haat. Ook Jezus' uitspraak aan het kruis in Lucas 23:34 ("Jezus zei: 'Vader, vergeef hun, want ze weten niet wat ze doen."') benadrukt de onschuld van Jezus en toont de doorbreking van het mechanisme van de zondebok (Girard 1986:122-134; Girard \& Williams 1996:145-188).

Het werk van René Girard is omstreden, sommige kringen zwijgen hem dood, anderen bekritiseren hem fel, maar hij heeft onmiskenbaar ook een grote schare volgelingen. Zijn wijze van argumentatie is soms onnavolgbaar en zijn omgang met de bronnen valt soms niet goed te controleren en komt willekeurig over. Uit Girard's model spreekt de ambitie om een alomvattende verklaring van geweld te geven, maar hij maakt feitelijk een onderscheid tussen primitieve en moderne samenlevingen. Mark Juergensmeyer stelt voor om offer en zondebok als centrale begrippen in de verklaring van geweld te vervangen door kosmische oorlog (zie paragraaf 5). Een belangrijke verschuiving in de godsdienstwetenschap maakt een algemene verklaring van het verband tussen religie en geweld weinig aannemelijk: de aandacht verschuift van het verschijnsel naar de actanten, dus van religie naar religieuze mensen. Daarmee wordt de verhouding tussen religie en geweld 
ambigu, zoals blijkt uit het onderscheid dat Scott Appleby (2000) maakt tussen "strong religion" en "weak religion": in het geval van "strong religion" nemen religieuze leiders hun verantwoordelijkheid, aanvaarden gelovigen de andersheid van de ander en zijn zij met de ander begaan, investeren zij in vredesopvoeding enzovoort, in geval van "weak religion" gebeurt dit alles niet.

\section{REGINA SCHWARTZ}

Het boek The curse of Cain: The violent legacy of monotheism van Regina M Schwartz (1997) veroorzaakte direct na de verschijning ruim tien jaar geleden veel ophef onder bijbelwetenschappers. Regina Schwartz is professor in Engelse Letterkunde aan Northwestern University, maar zij geeft ook les in Hebreeuwse Bijbel/Oude Testament. Zij kiest in haar boek een ander perspectief dan Girard. Het gaat haar niet om religie in algemene zin of om de menselijke cultuur, maar om de vraag of geweld inherent is aan het monotheïsme. Haar antwoord daarop is "nee, niet noodzakelijk", maar ze maakt in haar boek aannemelijk dat er feitelijk veel geweld plaatsvond in de wereld van het Oude Israël en het Jodendom.

In het begin van The curse of Cain vraagt Schwartz zich af waarom God het offer van Kaïn (Gen 4) veroordeelde. Daarmee staat direct de wisselwerking tussen het geloof in de Enige God en geweld centraal (Schwartz 1997:3). ${ }^{6}$ Het boek gaat in feite over de samenhang tussen collectieve identiteit en geweld in verband met de monotheïstische godsdienst van het Oude Israël. ${ }^{7}$ Daarbij zijn verbond, land en bloedverwantschap de sleutelbegrippen. Door identiteitsprocessen centraal te stellen en geweld als een uitkomst op te vatten van de vorming van de eigen identiteit in onderscheid met de identiteit van de ander, sluit Schwartz aan bij de omschrijving van geweld door Hent de Vries (zie paragraaf 2): "violence is the very construction of the other ..." (Schwartz 1997:5).

\footnotetext{
${ }^{6}$ Schwartz concentreert zich op de Joodse Bijbel/het Oude Testament omdat deze Bijbel bepalend is voor de westerse cultuur, maar dat is het Nieuwe Testament natuurlijk evenzeer. Schwartz richt zich vooral op de Bijbelse periode, maar maakt soms ook opmerkingen over de receptie van de Bijbel, zoals over Josiah Priest (1843), die zijn racistische biologie en legitimering van de slavernij van Afrikanen baseerde op de vloek over Ham/Kanaän in Gen 9:25-26.

${ }^{7}$ Schwartz beschouwt de facto de gehele Joodse Bijbel als een monotheïstisch document, maar andere geleerden wijzen erop dat aanzienlijke gedeelten van de Hebreeuwse Bijbel/het Oude Testament uit een pre-monotheïstische periode dateren. Dat heeft grote consequenties voor de beoordeling van het verband tussen monotheïsme en geweld, zoals Rainer Albertz betoogde in zijn lezing "Monotheism and violence - How to handle a dangerous Biblical tradition" voor de Nederlandse Onderzoekschool voor Theologie en Religiewetenschap op 12 maart 2008.
} 
Schwartz ziet dus drie samenhangende identiteitsprocessen weerspiegeld in de Joodse Bijbel/het Oude Testament, die ik hier achtereenvolgens kort zal samenvatten.

\subsection{Verbond met Israël}

Het verbond veronderstelt een wederkerige relatie tussen God en het volk, zoals bijvoorbeeld verwoord wordt in Leviticus 20:8: "Houd je aan mijn bepalingen en leef ze na; ik ben de HEER, ik heilig jullie."8 Schwartz benadrukt dat deze verbondsrelatie afscheiding van anderen met zich meebrengt, zoals het vervolg van Leviticus 20 laat zien: "Wees heilig omwille van mij, want ik, de HEER, ben heilig en ik heb jullie van de andere volken onderscheiden om mijn volk te zijn" (Lev 20:26). Schwartz (1997:59) concludeert: "monotheism legislates separation". De identiteit van Israël als het volk van het verbond is gefundeerd in de trouw aan de enige, transcendente God. Dit is tegelijkertijd een afgrenzende identiteit. "Monotheism is a myth that grounds particular identities in universal transcendence ... it forges identity antithetically - against the Other" (Schwartz 1997:16). "Violence is not, then, a consequence of defining identity as either particular or universal. Violence stems from any conception of identity forged negatively, against the Other, an invention of identity that parasitically depends upon the invention of some Other to be reviled" (Schwartz 1997:88 over Ezra 9). Israël mag geen andere goden vereren (Eks 20:5-6) en moet afstand bewaren tot andere volken. Daarom wordt de verbondsrelatie vaak symbolisch aangeduid als trouw aan God als partner, bijvoorbeeld Hosea 1-2 en Ezechiël 16 (Schwartz 1997:71; vgl Brenner \& van Dijk-Hemmes 1993). De radicaliteit van het unieke verbond met God en de afscheiding van anderen blijkt uit de rituele bezegeling van het verbond met offers, waarbij opvalt dat het verbond letterlijk wordt "gesneden" (karat berit) met het volledig doormidden snijden van de offerdieren (Gen 15:5-21; Eks 24:3-8; Jer 34:18). Schwartz kritiseert Girard, omdat vervangende offers maar ten dele het oorspronkelijke slachtoffer van geweld kunnen vervangen. Zij noemt Genesis 22 en Exodus 32 als voorbeelden (Schwartz 1997:21-24; cf. 112-119).

\subsection{Het beloofde land}

De tweede basis van Israëls identiteit bestaat uit het door God aan Israël gegeven land (Gen 12:1-2 enz). Het land maakt Israël mede tot een volk (Schwartz 1997:41). In de historische boeken wordt deze relatie uitgedrukt met de beelden van eigenaar en pachter: God bezit het land en Israël pacht het. Deze verhoudingen leiden tot harde sancties tegen Israëls tegenstanders

\footnotetext{
${ }^{8}$ De Bijbelcitaten zijn ontleend aan de Nieuwe Bijbelvertaling.
} 


\section{Religie, Bijbel en geweld}

en tegen Israël zelf in geval van ongehoorzaamheid. In Jozua 23:16 lezen we bijvoorbeeld: "Wanneer u andere goden gaat dienen en u voor ze neerbuigt, zal hij u wegvagen uit dit goede land dat hij u gegeven heeft. Dan zal zijn woede tegen $u$ losbarsten en zult $u$ heel snel worden weggevaagd uit dit goede land, dat u van hem gekregen hebt" (vgl 2 Kon 21:12-15). Schwartz komt in dit verband ook terug op een vraag uit haar voorwoord die aanleiding tot het schrijven van haar boek was: Wat gebeurde er met de Kanaänieten? Sommige Bijbelse passages stellen onomwonden dat Gods gave van het land gepaard ging met de vernietiging van eerdere bewoners. In Deut 7:2 lezen we de volgende oproep van God aan Israël: "Wanneer de HEER, uw God, u de overwinning op hen schenkt, moet $u$ hen doden. $U$ mag geen vredesverdrag met hen sluiten en hen niet sparen" (vgl Jos 24:11-13).

\subsection{Verwantschapsmythen}

Ook de derde bron van Israëls identiteit, bloedverwantschap, is een vorm van identiteit die ten koste van anderen gaat. Niet-Israëlieten worden niet als mensen gezien, als onrein beschouwd. Zij leiden tot verafschuwing en moeten in sommige gevallen zelfs gedood worden op grond van de ban. De identiteit van Israël als volk op grond van bloedverwantschap geeft dus een negatieve identiteit aan niet-Israëlieten en roept geweld tegen hen op, zoals uit het verhaal over Dina en de Sichemieten in Genesis 34 blijkt. De Sichemieten waren bereid hun land en identiteit met de Israëlieten te delen, maar werden toch vermoord (Schwartz 1997:94-97).

Het boek van Regina Schwartz maakt de lezer er bewust van dat het geloof in de God van Israël tot geweld kan leiden, vooral tot geweld jegens anderen. Het is goed mogelijk dat lezers bepaalde details anders taxeren, maar het is aannemelijk dat het geweld dat uit de Joodse Bijbel/het Oude Testament opklinkt nauw samenhangt met identiteitsprocessen zoals deze door Schwartz beschreven worden. In de marge van haar boek stelt Schwartz ook de vraag hoe moderne lezers met dit "Bijbelse geweld" om zouden kunnen gaan. Zij wijst daarbij op een trend in de Bijbel die niet de nadruk legt op particulariteit, maar op openheid voor anderen, waardering voor pluraliteit, veelheid en diversiteit. Een sleuteltekst voor haar in dit verband is Jesaja 56:3-8:

De vreemdeling die zich met de HEER heeft verbonden, laat hij niet zeggen: "De HEER zondert mij zeker af van zijn volk." En laat de eunuch niet zeggen: "lk ben maar een dorre boom." (4) Want dit zegt de HEER: De eunuch die mijn sabbat in acht neemt, die keuzes maakt naar mijn wil, die vasthoudt aan mijn verbond, (5) hem geef ik iets beters dan zonen en dochters: een gedenkteken 
en een naam in mijn tempel en binnen de muren van mijn stad. Ik geef hem een eeuwige naam, een naam die onvergankelijk is.

Helaas werkt Schwartz deze lijn in haar betoog nauwelijks uit (Schwartz 1997:33-34; 87-88; 117-119). Zij stelt eveneens voor (Schwartz 1997:158) om de grenzen van de canon te doorbreken door een voortschrijdend proces van herinnering en herschrijving van de Bijbelse tradities.

\section{MARK JUERGENSMEYER}

Hoewel het werk van Mark Juergensmeyer nauwelijks ingaat op geweld in de Bijbel - wel op geweld geïnspireerd door de Bijbel - wil ik hem hier om twee redenen toch bespreken: Juergensmeyer wijst op de performatieve aspecten van geweld en benadrukt tevens dat religieus geïnspireerde, negatieve stereotyperingen van mensen gewelddadige consequenties kunnen hebben.

Mark Juergensmeyer is hoogleraar in internationale studies, sociologie en religiestudies aan de University of California, Santa Barbara. Hij heeft onder meer gepubliceerd over Mahatma Gandhi, maar verwierf recent wereldwijd bekendheid met zijn boek Terror in the mind of God (Juergensmeyer 2003). Juergensmeyer betoogt in dit boek dat terroristische acties over de gehele wereld duidelijk toenemen en dat deze terreur tegenwoordig meer en meer geïnspireerd wordt door religieuze overtuigingen. Hij stelt dat religie aan de daders de morele houding verschaft die de toepassing van terreur legitimeert en ook bijdraagt aan de ideologie, de symbolen en de rituelen die met het geweld gepaard gaan. Verder draagt religie soms ook bij aan de organisatie-structuur van terroristische groepen, direct of indirect via een "community of support". 9

Juergensmeyer stelt echter dat religieus geïnspireerde daden van terrorisme niet het monopolie zijn van één bepaalde godsdienst, zoals sommigen denken met betrekking tot de Islam. Ook niet-monotheïstische godsdiensten zoals de religie van de Sikhs of het Boeddhisme kunnen gelovigen tot terroristische acties brengen. Juergensmeyers boek bestaat uit twee gedeelten: het eerste deel biedt case studies die gebaseerd zijn op interviews met slachtoffers, daders en leden van hun community of support. In het tweede deel ontwikkelt Juergensmeyer een theoretisch model dat verklaart waarom en hoe religie en terroristisch geweld samenhangen. Eén

\footnotetext{
${ }^{9}$ Vergelijk Juergensmeyer (2003:xi): "In this book I explore this dark alliance between religion and violence .... Religion is crucial for these acts, since it gives moral justifications for killing and provides images of cosmic war that allow activists to believe that they are waging spiritual scenarios. This does not mean that religion causes violence, nor does it mean that religious violence cannot, in some cases, be justified by other means. But it does mean that religion often provides the mores and symbols that make possible bloodshed - even catastrophic acts of terrorism."
} 


\section{Religie, Bijbel en geweld}

van de hoofdstukken uit het eerste deel gaat over de Amerikaanse predikant Mike Bray, die in 1985 veroordeeld werd wegens gewelddadige acties tegen artsen en verpleegkundigen die abortus provocatus uitvoerden. Ds Bray, die tot de Reformed Lutheran Church behoort, schreef een boek getiteld $A$ time to kill (Bray 1994) en zat een gevangenisstraf uit tot 1989 (Juergensmeyer 2003:20-36).

Het voert te ver om hier op alle aspecten van Juergensmeyers uitvoerige studie in te gaan. De sleutel tot de verklaring van het verband tussen religie en terreur is het centrale begrip kosmische oorlog (cosmic war). Oorlog, en niet een cyclus van offers, is de bepalende factor bij religieus geweld. ${ }^{10}$ Juergensmeyer leidt dit af uit uitspraken van daders. Het standpunt van Bin Laden dat de Amerikanen de oorlog verklaard hebben tegen God, de Profeet en in feite alle Moslems met hun optreden in het Midden-Oosten, is een van de voorbeelden die hij ter onderbouwing van zijn visie geeft. Ds Mike Bray is een ander voorbeeld; Bray vergelijkt de situatie in Amerika rond de wetgeving en praktijk van abortus met de tweede wereldoorlog. Vaak heeft deze oorlog een universeel karakter én een eschatologische dimensie. Het gaat om de ultieme confrontatie tussen goed en kwaad, zoals uit uitspraken van Master Asahara van de Aum Shinrikyo sekte blijkt, die met de actie met Sarin gas in de ondergrondse van Tokyo het aanbreken van het einde der tijden wilde forceren. Oorlog krijgt zo een dubbele betekenis: het biedt de context waarin de terroristische acties plaatsvinden in de perceptie van de daders, en het geeft ook een symbolische duiding van de hedendaagse situatie. Oorlog verklaart zo de werkelijkheid, geeft aan wie de held en wie de slechterik is, en legitimeert de riten van geweld. Ook al gaat het niet om een totale oorlog, het terroristische geweld in het perspectief van een kosmische oorlog legitimeert het bestaan van de eigen gemeenschap, vernedert de tegenstander en ontneemt hem op zijn minst tijdelijk zijn macht (Juergensmeyer 2003:148-189).

Het perspectief van een kosmische oorlog verleent dus macht aan de daders, werkelijke macht op het moment van hun daad of in de korte periode daarna, of symbolische macht. Het suggereert dat de terroristen in feite slachtoffers zijn en legitimeert het geweld tegen hun vijand, die in het kader van de radicale dualistische tegenstelling die de kosmische oorlog veronderstelt gedemoniseerd wordt. De terroristische daad is zo een overwinning op de vijand, al was het maar door een tijdelijke symbolische omkering van rollen (symbolic empowerment). Juergensmeyer kijkt dus naar het effect van terroristisch geweld. Daarbij sluit hij aan bij de Latijnse

\footnotetext{
${ }^{10}$ Dit verklaart Juergensmeyers kritiek op Girard (Juergensmeyer 2003:164-166, 171-173), voor wie offer en zondebok de centrale begrippen zijn.
} 
achtergrond van het woord terreur: terrere betekent in het Latijn "angst aanjagen", het gaat om het effect op de doelgroep en de omstanders: “... public acts of destruction, committed without a clear military objective, that arouse a widespread sense of fear" (Juergensmeyer 2003:5). Dit effect moet zo groot mogelijk zijn en dat verklaart waarom terreurdaden zo vaak een spectaculair en ritueel karakter hebben. Tijd, plaats, en publiek worden daarbij met zorg uitgezocht, om een maximaal effect tot stand te brengen. Dat blijkt bijvoorbeeld uit het opblazen van het centrale federale gebouw in Oklahoma City door Timothy McVeigh op 19 april 1995. 19 april is in de Verenigde Staten Patriot's Day, waarop het begin van de Amerikaanse Revolutie in 1775 herdacht wordt. Het is ook de dag waarop de actie van de Nazi's tegen de Joden in het getto van Warshaw in 1943 begon en waarop de Branch Davidians van David Koresh in hun ranch in Waco in 1993 de dood vonden (Juergensmeyer 2003:135-36).

Juergensmeyers theorie is belangrijk omdat hij met zijn aandacht voor de performatieve dimensie van extreem geweld laat zien dat dit geweld nauw met machtsprocessen verbonden is, zowel reëel als symbolisch. Daarnaast toont hij aan hoe de tegenstanders in het kader van de kosmische oorlog negatief gestereotypeerd worden, waarmee alle geweld tegen hen geoorloofd lijkt te zijn. Er is ook kritiek mogelijk op Juergensmeyers benadering. De rol van religie bij de terroristische daden die hij bespreekt blijtt soms onduidelijk en niet-religieus geïnspireerde terroristen vertonen hetzelfde gedrag als religieuze extremisten. ${ }^{11}$ Juergensmeyer kan evenmin verklaren waarom de ene extremistische gelovige wel kiest voor het plegen van een terreurdaad en de andere niet, daarvoor zou hij bij andere verklaringsmodellen te rade moeten gaan (bijvoorbeeld het staircase model van Moghaddam 2005).

\section{J HOWARD ELLENS}

Met het werk van $\mathrm{J}$ Howard Ellens keren we terug naar het vraagstuk van het geweld in de Bijbel, niet alleen de Hebreeuwse Bijbel/het Oude Testament, maar ook het Nieuwe Testament. J Howard Ellens is een kolonel van het Amerikaanse leger, die na zijn pensionering een tweede carrière begon aan de universiteit. Hij is emeritus hoogleraar in de filosofie, psychologie en theologie. Enkele jaren geleden gaf hij een omvangrijk werk uit onder de titel The destructive power of religion, violence in Judaism, Christianity, and Islam

\footnotetext{
${ }^{11}$ Dat is bijvoorbeeld het geval bij zijn bespreking van terroristen in Noord-lerland (Juergensmeyer 2003:36-43, 122). De "Shankhill butchers" van Kenny McClinton werden beschuldigd van meer dan dertig brute moorden, waarbij McClinton toegaf dat hij had aangespoord tot het onthoofden van Rooms-Katholieken en het spietsen van hun hoofden op het hek van een park in de Protestantse wijk Shankhill, maar het is zeer de vraag of zijn groep zich werkelijk door religieuze motieven liet leiden.
} 


\section{Religie, Bijbel en geweld}

(2004). In 2007 verscheen hiervan een bijgewerkte en ingekorte versie in één band (Ellens 2004; 2007). Ellens is niet alleen de redacteur van beide werken, maar ook de auteur van verschillende bijdragen daarin, die duidelijk de toon zetten voor het project als geheel. De impact van 11 September 2001 en de dreiging van Moslim terrorisme vormen een belangrijke aanleiding voor Ellens boeken. Daarnaast is de geestesgesteldheid van veel mensen in het westen een punt van grote zorg, omdat deze sterk bepaald wordt door de metafoor van een conflict op wereldschaal (cosmic conflict, Ellens 2007:36, 101, 114115; vergelijk Juergensmeyer).

Ellens en zijn mede-auteurs stellen zich de vraag hoe geweld ter sprake komt in de heilige geschriften van Joden, christenen en Moslims. ${ }^{12}$ Dat gebeurt onder meer in metaforen en uitspraken over "de ander" binnen en buiten de eigen religieuze gemeenschap. Met betrekking tot de Bijbel concludeert Ellens dat geweld een prominent thema is in beide testamenten en dat de houding die de Bijbel tegenover geweld inneemt principieel ambivalent is: de Joodse en de christelijke godsdienst hebben de potentie om zowel destructieve als positieve krachten los te maken. Hij gaat er daarbij vanuit, met Robert McAfee Brown and Michael Desjardins (zie paragraaf 2), dat geweld ook een niet-fysiek karakter kan hebben.

Ellens betoogt dat de destructieve krachten van religie nauw samenhangen met de Bijbelse metaforen van een oorlogvoerende God, het beeld van God die zijn eigen Zoon opoffert, en het apocalyptische wereldbeeld dat tot een radicaal dualisme leidt in de context van een kosmisch conflict. Deze beelden resulteren in een psychologisch archetype bij de mensen dat oproept tot het zoeken van "final solutions", die vaak tot geweld tegen anderen leiden en dat geweld ook legitimeren. De psychologie kan weinig ondernemen tegen deze metaforen met een dodelijke uitwerking, maar de lezer van de Bijbel kan dat wel: de gewelddadige metaforen en beelden in de Bijbelteksten moeten met wortel en tak uitgeroeid worden en vervangen door beelden met een opbouwende strekking (Ellens 2007:56-57).

Walter Wink levert een belangrijke bijdrage aan beide werken van Ellens (Wink 2007a; 2007b). Wink waarschuwt voor het paradigma van overheersing, het "dominion system". Deze mythe veronderstelt dat alleen geweld verlossing kan brengen en dat God diegene steunt die overwint. Wink stelt dat dit paradigma overheersend was in de antieke culturen, maar ook tegenwoordig nog belangrijk is, met name in de Amerikaanse samenleving

\footnotetext{
${ }^{12} \mathrm{lk}$ concentreer mij in het vervolg van deze paragraaf op de Bijbel, maar de werken van Ellens bevatten ook behartenswaardige bijdragen over de Islam, onder meer in een hoofdstuk van Ellens zelf over Jihad, dat principieel een positief concept is omdat het het doen van Gods wil beoogt (Ellens 2007:150-160).
} 
(Wink 2007a). Hij roept op tot een tegengesteld paradigma, dat zich toespitst op het zoeken van God in de vijand, in liefde en vergeving. Hij werkt dit paradigma uit in wat hij de "derde weg" van Jezus noemt, niet de weg van het conflict, evenmin de weg van het pacifisme, maar een weg van nietgewelddadig verzet, dwingend maar zonder gewelddadige consequenties. Hij werkt deze derde weg uit met zijn interpretatie van Jezus' uitspraken in de Bergrede over het toekeren van de linkerwang (Matt 5:38-39), het geven van het bovenkleed (Matt 5:40) en het oplopen van een tweede mijl (Matt 5:41). Wink leidt hier een hele lijst met richtsnoeren voor het omgaan met de ander van af (Wink 2007b:190-191, 225). Ellens sluit aan bij Winks pleidooi en benadrukt dat de mensen zelf moeten streven naar een verantwoorde samenleving die niet door geweld gedomineerd wordt. ${ }^{13}$ Ellens afsluitende bijdrage aan de bundel uit 2007 vertelt het verhaal over de reis van Laura Blumenfeld, wiens vader in 1986 door een Palestijn neergeschoten werd (Blumenfeldt 2002). Blumenfeld zint op wraak en zoekt in cognito de familie van de dader op. Zij krijgt haar vergelding in zekere zin, maar niet volgens het principe van "oog om oog, tand om tand". Het verhaal toont op ontroerende wijze dat vergeving van ons mensen afhankelijk is.

Ook tegen sommige punten uit de studies van Ellens kan bezwaar aangetekend worden. Zo is het verre van vanzelfsprekend dat fundamentalistische Joden, Moslims of Christenen hun toevlucht tot extreem geweld nemen, zoals sommige bijdragen lijken te veronderstellen. Twee hoofdlijnen uit dit werk zijn echter belangrijk voor ons thema:

- $\quad$ Ellens observeert dat zowel de Joodse Bijbel/het Oude Testament als het Nieuwe Testament principieel een ambivalente houding laat zien.

- $\quad$ Ellens werk leidt tot de radicale vraag hoe wij in de eenentwintigste eeuw om moeten gaan met het geweld in de Bijbel. Moeten we de gewelddadige passages eenvoudig schrappen uit de Bijbeltekst, zoals Ellens oppert, of moeten we kiezen voor de optie van "een canon binnen de canon" en aansluiten bij die passages die wijzen in de richting van een alternatieve weg, zoals Winks essays over de derde weg van Jezus betogen? Of moeten we accepteren dat geweld onderdeel is van onze religieuze traditie en proberen daar zo verantwoord mogelijk mee om te gaan?

${ }^{13}$ Ellens (2007:102-103, 234) sluit hier eveneens aan bij Kushner (1981). 


\section{Religie, Bijbel en geweld}

\section{CONCLUSIE}

Tijdens onze conferentie zullen we uitgebreid ingaan op passages uit het Nieuwe Testament en eveneens de sociaal-politieke en culturele context waarin de eerste volgelingen van Jezus leefden bij onze bestudering van het thema van het geweld in het Nieuwe Testament betrekken. Ik hoop dat de hier besproken theorieën over religie en geweld daarbij een richtsnoer kunnen zijn. Ik vat daartoe de belangrijkste punten kort samen:

Girard en Ellens impliceren dat het Nieuwe Testament een ambivalent beeld laat zien ten aanzien van geweld, simpel gezegd: het Nieuwe Testament roept op tot vrede maar ook tot geweld, direct of indirect (dit is ook de belangrijkste conclusie van Desjardins 1997). Naast Jezus' uitspraken in de Bergrede met een vredelievende strekking (Matt 5:9, 38-45) klinken heel andere woorden in Matteüs 10:34-39, beginnend met "Denk niet dat ik gekomen ben om op aarde vrede te brengen. Ik ben niet gekomen om vrede te brengen, maar het zwaard" (Matt 10:34).

Schwartz en Ellens betogen dat de beeldspraak en het woordgebruik in de Bijbel regelmatig geweld oproept, doordat het tot een archetype leidt dat geweld tegen anderen legitimeert. Ellens impliceert dat dit ook voor het Nieuwe Testament het geval is, waarbij aan Jezus' woorden over het Laatste Oordeel in Matteüs 25:31-46 of Paulus' beschrijving van een gewelddadig einde van de wereld in Filippenzen 1:28 en 1 Tessalonicenzen 5:3 gedacht kan worden, maar ook aan passages over de kruisdood van Christus (zie ook Gager 2005). Is dit inzicht juist? Zo ja, hoe kunnen wij daarmee omgaan?

Schwartz werkt uit hoe geweld in de Joodse Bijbel/het Oude Testament samenhangt met identiteitsprocessen die vaak tot uitsluiting van "de ander" binnen en buiten de eigen gemeenschap leiden. Dit inzicht is ook relevant voor het Nieuwe Testament, waarbij een verband gelegd kan worden met Juergensmeyers observaties over de negatieve stereotypering en zelfs demonisering van tegenstanders in de context van een sterk dualistisch wereldbeeld. Dit lijkt een nieuw licht te werpen op bijvoorbeeld de passages over "de Joden" en "de zogenaamde Joden" (Joh 8:44; 9:22; 34; 12:42-45; 16:2; Op 2:9; 3:9; vgl 2:14-16, 20-24), maar ook op andere passages waarin de identiteit van de eigen groep en anderen tegenover elkaar staan.

Ellens roept de hermeneutische vraag op hoe wij met de gewelddadige passages in het Nieuwe Testament om moeten gaan. Velen zullen terugdeinzen voor zijn radicale voorstel om deze passages te schrappen uit de canon, maar daarmee wordt de vraag des te prangender. Daarbij moeten we ook oog hebben voor de mogelijke uitwerking van deze passages op "de ander". Wanneer wijzelf tot een verantwoorde uitleg van passages die geweld 
kunnen oproepen komen, is die uitleg dan ook overtuigend voor de ander? (vgl Reinhartz 2001).

\section{Geciteerde literatuur}

Albertz, R 2008. Monotheism and violence: How to handle a dangerous Biblical tradition. Lezing voor de Nederlandse Onderzoekschool voor Theologie en Religiewetenschap op 12 maart 2008.

Appleby, R S 2000. The ambivalence of the sacred: Religion, violence, and reconciliation. Lanham, MD: Rowman \& Littlefield.

Arendt, H 1970. Geweld / macht en onmacht. Vertaald door M Mok. Antwerpen: Het Spectrum.

Blumenfeldt, L 2002. Revenge: A story of hope. New York: Simon \& Schuster.

Brenner, A 2004. "On the rivers of Babylon" (Psalm 137), or between victim and perpetrator, in Bekkenkamp, J \& Sherwood, Y (eds), Sanctified aggression, 76-91. London: Continuum.

Brenner, A, \& Van Dijk-Hemmes, F 1993. On gendering texts: Female and male voices in the Hebrew Bible. Leiden: Brill.

Coetzee, J M 1980. Waiting for the barbarians. London: Secker \& Warburg.

Desjardins, M 1997. Peace, violence and the New Testament. Sheffield: Sheffield Academic Press.

Ellens, J H (ed) 2004. The destructive power of religion: Violence in Judaism, Christianity, and Islam, Vier delen. Westport, CT: Praeger.

Ellens, $\mathrm{J} \mathrm{H}$ (ed) 2007. The destructive power of religion: Violence in Judaism, Christianity, and Islam, Condensed and updated version. Westport, CT: Praeger.

Gager, J 2005. Violent acts and violent language in the apostle Paul, in Matthews, S \& Gibson, $\mathrm{E} L$ (eds), Violence in the New Testament, 13-21. New York: T \& T Clark International.

De Vries, H 2002. Religion and violence. Baltimore, MD: Johns Hopkins University Press.

Girard, R 1977. Violence and the sacred. Baltimore, MD: Johns Hopkins University Press.

Girard R 1986. De zondebok. Kampen: Kok.

Girard R 2001. I see Satan fall like lightning. Maryknoll, NY: Orbis Books.

Girard R, Oughourlian, J-M \& Lefort, G 1987. Things hidden since the foundation of the world. Stanford, CA: Stanford University Press.

Girard, R, \& Williams, J 1996. The Girard reader. New York: Crossroad.

Juergensmeyer, M 2003. Terror in the mind of God: The global rise of religious violence. Berkeley, CA: University of California Press.

Kushner, H 1981. When bad things happen to good people. New York: Schoken Books.

Lascaris, A 1987. Advocaat van de zondebok: Het werk van René Girard en het evangelie van Jezus. Hilversum: Gooi \& Sticht.

Vos, J S 2006. The destructive power of atonement theology. Neotestamentica 40, 383-401. 
Moghaddam, F M 2005. The staircase to terrorism: A psychological exploration. Am Ps 60, 161-169.

Reinhartz, A 2001. Befriending the beloved disciple: A Jewish reading of the Gospel of John. New York: Continuum.

Schwartz, R M 1997. The curse of Cain: The violent legacy of monotheism. Chicago, IL: University of Chicago Press.

Van Dale, J H, Kruyskamp, C, Calisch, I M (reds) 1976. Groot Woordenboek der Nederlandse Taal. Tiende, geheel opnieuw bewerkte en zeer vermeerderde druk door Dr C Kruyskamp. Twee delen. Den Haag: Nijhoff.

Wink, W 2007a. The myth of redemptive violence, in Ellens, J H (ed), The destructive power of religion: Violence in Judaism, Christianity, and Islam, 161-179. Westport, CT: Praeger.

Wink, W 2007b. Beyond just war and pacifism: Jesus' nonviolent way, in Ellens, J H (ed), The destructive power of religion: Violence in Judaism, Christianity, and Islam, 180-199. Westport, CT: Praeger.

Yoder, J H 1972. The politics of Jesus. Grand Rapids, MI: Eerdmans. 